Ryszard KOWALCZYK

Uniwersytet im. Adama Mickiewicza, Poznań

\title{
Ilościowe i jakościowe przeobrażenia prasy lokalnej w Polsce w latach 90. XX wieku
}

\section{Podstawy przeobrażeń ilościowych}

\subsection{Prasa podziemna}

K limat sprzyjający odbudowie współczesnej prasy lokalnej tworzyły - między innymi tytuły kolportowane w podziemiu w latach osiemdziesiątych. Prasa ta odegrała niezwykle ważną rolę w edukowaniu i aktywizowaniu na ogół biernego społeczeństwa. Ponadto stała się ośrodkiem, wokół którego gromadziły się elity społeczne i polityczne. W czasopismach podziemnych otrzymywali szlify dziennikarskie przyszli wydawcy i redaktorzy prasy lokalnej, która po zniesieniu cenzury mogła dynamicznie się rozwijać. Szczególną aktywność prasowo-wydawniczą pod koniec lat 80 . wykazywały podziemne struktury związku zawodowego „Solidarność" oraz oddziały terenowe powstałego w grudniu 1988 roku Komitetu Obywatelskiego przy Lechu Wałęsie. Ważne znaczenie, lecz w nieco mniejszej skali społecznej, miały wydawnictwa różnych partii, stronnictw i związków nielegalnej opozycji politycznej.

Aktywna działalność wydawnictw podziemnych stanowiła materialny wyraz ograniczeń systemowych, jakie istniały zarówno w dostępie do wiarygodnych i rzetelnych informacji, jak i możliwościach ich rozpowszechniania. Z drugiej strony odzwierciedlała skalę niezaspokojonych dotąd potrzeb informacyjnych mieszkańców, które krystalizowały się wraz z instytucjonalizacją form i metod działania nielegalnej opozycji politycznej.

\subsection{Prasa legalna}

Na przeciwnym biegunie wydawnictw prasowych znajdowały się legalnie rozpowszechniane pisma lokalne, wydawane najczęściej przez różne stowarzyszenia oraz terenowe oddziały Patriotycznego Ruchu Odrodzenia 
Narodowego (PRON). Wraz z tytułami ogólnoinformacyjnymi, stanowiącymi najczęściej rodzaj kroniki miejscowego życia społeczno-politycznego, kulturalnego i gospodarczego, ukazywały się ambitniejsze formy prasowo-wydawnicze, do których można zaliczyć regionalne czasopisma popularnonaukowe. Na trzeci rodzaj piśmiennictwa lokalnego składały się periodyki wydawane przez terenowe agendy organizacji młodzieżowych, takich jak ZSMP, ZMW, ZHP. Specyficzną kategorię wydawnictw lokalnych tworzyła prasa zakładowa, która na przełomie lat osiemdziesiątych przeżywała wyraźny kryzys ${ }^{1}$. Do przedostatniej grupy miejscowych pism zalicza się różnorodne tytuły społeczno-polityczne i kulturalne kolportowane w większych miastach i na obszarze byłych powiatów, których wydawcami były często miejscowe komitety PZPR. Należy również wspomnieć o prasie komitetów obywatelskich, która ukazywała się w początkowym okresie bez wymaganych prawem zezwoleń. Rozwijała się ona dynamicznie po wygranych przez opozycję czerwcowych wyborach parlamentarnych 1989 roku. Szczególną rolę odegrały pisma lokalnych komitetów obywatelskich w czasie kampanii wyborczej do samorządu terytorialnego w maju 1990 roku.

\subsection{Polityczne determinanty}

Nowe warunki rozwoju prasy, jakie powstały pod koniec lat 80., były wynikiem decyzji politycznych. Obrady „okragłego stołu” (6 luty - 5 kwietnia 1989 roku) określiły podstawowe zadania i rolę mediów w Polsce. W przyjętych ustaleniach wyznaczono środkom komunikowania społecznego określone funkcje, których realizacja polegała w szczególności na dostarczaniu mieszkańcom rzetelnych informacji, wyrażaniu zróżnicowanej opinii społecznej, kontrolowaniu władzy, a także ujawnianiu i łagodzeniu konfliktów społecznych oraz współdziałaniu we wprowadzaniu reform demokratycznych ${ }^{2}$. W konsekwencji więc niezależne media miały stanowić jeden z zasadniczych instrumentów sprawowania kontroli nad działalnością władz i instytucji publicznych oraz środek wyrażania plu-

1 Por. R. Kowalczyk, Cele i zadania prasy zakładowej w poznańskiem (1981-1991), Poznań 1994; idem, Wczoraj i dziś prasy lokalnej w Polsce, Poznań 2002, s. 251.

2 Zob. Sprawozdanie z prac Podzespolu ds. Środków Masowego Przekazu z 22 III 1989 r., w: Porozumienia Okragłego Stołu, Warszawa 6 II-5 IV 1989, wyd. NSZZ „Solidarność” Region Warmińsko-Mazurski, Olsztyn 1989, s. 71-83. 
ralistycznej opinii społecznej, a także filar społeczeństwa obywatelskiego, które kształtuje się w nieustannej debacie publicznej.

Podstawowy wpływ na rozwój prasy lokalnej po 1989 roku posiadały procesy społeczno-politycznej i ekonomicznej transformacji systemowej. Jej wyrazem stała się między innymi demokratyzacja życia społecznego i politycznego, liberalizacja gospodarki oraz decentralizacja władzy ${ }^{3}$. Istotny wpływ na przeobrażenia mediów miał proces ich demonopolizacji i prywatyzacji oraz zastosowanie w działalności wydawnictw nowoczesnych rozwiązań techniczno-technologicznych i organizacyjnych.

W tych warunkach rozpoczął się złożony i wieloletni proces przechodzenia od państwowo-partyjnego systemu monopolistyczno-centralistycznego ${ }^{4}$ do prywatnego systemu pluralistycznego o charakterze komercyjnym. W wyniku tych przeobrażeń systematycznie zwiększały się udział i rola kapitału zagranicznego w polskich wydawnictwach prasowych ${ }^{5}$. Istotny wpływ na skalę i dynamikę tych zjawisk posiadały także zmiany w prawie prasowym $^{6}$.

\subsection{Społeczne determinanty}

Intensywny rozwój periodyków miejscowych stanowił rezultat wzmożonego wysiłku organizacyjnego i finansowego oraz olbrzymiego zaanga-

3 Por. Przeobrażenia ustrojowe $w$ Polsce, pod red. E. Zielińskiego, Warszawa 1993; Polska w procesie przeobrażeń ustrojowych, pod red. S. Wróbla, Katowice 1998.

4 Rolę szczególną w tym procesie odegrały nowe rozwiązania prawne, jakie wprowadzono ustawą z dnia 22 marca 1990 roku o likwidacji Robotniczej Spółdzielni Wydawniczej „Prasa-Książka-Ruch” (Dz. U. 1990, Nr 21, poz. 125).

5 Szerzej na temat transformacji rynku prasowo-wydawniczego w Polsce zob.: Transformacja prasy polskiej (1989-1992), pod red. A. Słomkowskiej, Warszawa 1992; Dylematy transformacji prasy polskiej (1989-1993), pod red. A. Słomkowskiej, Warszawa 1994; Transformacja mediów (1989-1995), pod red. A. Słomkowskiej, Warszawa 1996; Media i dziennikarstwo w Polsce (1989-1995), pod red. G. Kopper, I. Rutkiewicz, K. Schliep, Kraków 1996; Z. Bajka, Kapitał zagraniczny w polskiej prasie - lata dziewięćdziesiate, „Zeszyty Prasoznawcze” 1998, nr 1/2, s. 21-35.

6 Warto zwrócić uwagę na ustawę z dnia 11 kwietnia 1990 roku o uchyleniu ustawy o kontroli publikacji i widowisk, zniesieniu organów tej kontroli oraz o zmianie ustawy - Prawo prasowe (Dz. U. 1990, Nr 29, poz. 173). Więcej informacji na ten temat znajdzie czytelnik w pracach prof. zw. dr hab. Jacka Sobczaka, Prawo środków masowej informacji. Prasa-radio-telewizja, Toruń 1999; idem, Ustawa prawo prasowe. Komentarz, Warszawa 1999; idem, Prawo prasowe. Podręcznik akademicki, Warszawa 2000. 
żowania poszczególnych osób, grup, stowarzyszeń, lokalnych władz. Otwarty system komunikowania, który w poważnym stopniu współkształtowała prasa lokalna, stanowił jeden z niezwykle ważnych elementów nowego ładu społecznego i politycznego.

W ostateczności nie byłoby rozwoju prasy lokalnej bez wyraźnego zapotrzebowania na nią zgłaszanego przez mieszkańców. Gazety i czasopisma zaspokajając oczekiwania określonych społeczności, stawały się jednocześnie ważnym elementem systemu komunikowania społecznego. W wyniku aktywnej działalności rosła ich siła, a wraz z nią społeczna i polityczna użyteczność prasy lokalnej.

\subsection{Prawne i ekonomiczne determinanty}

Są one wyrazem rozpoczętego w 1989 roku procesu transformacji systemu społeczno-politycznego, ekonomicznego i ustrojowego państwa. Liberalizacja większości przepisów - krępujących dotychczas swobodny rozwój inicjatyw prasowo-wydawniczych w ogóle, a prasy lokalnej w szczególności - zaowocowała zniesieniem instytucji cenzury prewencyjnej i wprowadzeniem mechanizmów gospodarki rynkowej także w dziedzinie usług wydawniczych, produkcji prasowo-wydawniczej, kolportażu. Co zintensyfikowało i tak stosunkowo żywiołowy rozwój periodyków lokalnych.

Nowe warunki prawne, finansowe i społeczno-polityczne tworzyły dogodne podstawy funkcjonowania mediów, co sprzyjało dynamicznemu rozwojowi zróżnicowanych inicjatyw prasowo-wydawniczych. W rezultacie stosunkowo szybko zmieniał się miejscowy rynek prasy i usług wydawniczych. W konsekwencji żywiołowego rozwoju tej grupy pism w początkowym okresie, w następnych latach doszło do naturalnego, znacznego ograniczenia tej tendencji, czyli zmniejszenia liczby nowych inicjatyw prasowych. Aktywność prasowo-wydawnicza poszczególnych wspólnot charakteryzuje się stosunkowo dużą płynnością i podlega okresowym wahaniom.

\subsection{Czynniki przeobrażeń}

Na przemiany, jakim podlegał rozwój wydawnictw lokalnych wpływały takie czynniki, jak: 1) systematyczny wzrost liczby pism; 2) wzmagająca się w związku z tym konkurencja; 3) fluktuacja miejscowego 
piśmiennictwa, wyrażająca się likwidacją niektórych tytułów, w miejsce których powstawały nowe; 4) obejmowanie przez prasę lokalną coraz większych stref wpływów, co poszerzało zasięg jej oddziaływania i podnosiło znaczenie w środowisku; 5) wyraźna krystalizacja dwu podstawowych typów prasy lokalnej: znajdujących w gestii samorządów terytorialnych i w rękach prywatnych, przejawiająca się w specyficznym podziale zadań i funkcji tych wydawnictw; 6) dominacja pod względem nakładu, zasięgu kolportażu i wpływów społecznych, wielkonakładowych, jak na warunki lokalne, ogólnoinformacyjnych pism o większej częstotliwości ukazywania się (przeważnie prywatnych tygodników i dwutygodników).

\section{Liczbowy przyrost tytułów}

\subsection{Metody statystyczne badań prasy}

Podawane liczby tytułów prasowych ukazujących się w poszczególnych latach mogą być rezultatem dwóch charakterystycznych metod statystycznych badań prasy. Jedna, którą możemy nazwać dynamiczna, analizuje rzeczywistą liczbę pism ukazujących się w konkretnych latach. Stąd też badacz musi dysponować faktycznymi danymi ilustrującymi ruch prasowo-wydawniczy, jaki charakteryzował lokalny rynek. Metoda ta stosunkowo wiarygodnie odzwierciedla zmiany, jakie zachodziły w tym obszarze w poszczególnych okresach. Drugi sposób badań możemy określić jako statyczny. Podstawę stanowią wówczas pisma, które przetrwały do czasu przeprowadzania badań. W rezultacie metoda ta skupia się na badaniach stosunkowo trwalszych przejawów aktywności prasowo-wydawniczej. Nie uwzględnia jednak zmian zachodzących w poszczególnych latach, które odzwierciedlają różnicę, jaka istnieje między liczbą pism wydawanych i likwidowanych w danym okresie. Metoda statyczna, posiłkując się danymi współczesnymi, wykorzystuje je do poznania obrazu przeszłości. Natomiast metoda dynamiczna na podstawie ustaleń przeszłych próbuje wyjaśniać zjawiska współczesne.

\subsection{Wskaźniki liczbowe}

W następstwie badań o charakterze ilościowym otrzymuje się wiarygodny materiał statystyczny. Jest to podstawa umożliwiająca bezstronny 
opis i charakterystykę określonych zjawisk i tendencji, jakie towarzyszą kształtowaniu się rynku prasy lokalnej. Tę problematykę można badać zarówno na płaszczyźnie regionalnej, jak i ogólnopolskiej.

Na przykład w dawnym województwie poznańskim następował systematyczny przyrost tytułów miejscowej prasy, których liczba wzrosła z 31 w 1990 roku do 118 w 1998 roku$^{7}$. Podobną tendencję obserwuje się na obszarze nowego województwa wielkopolskiego, gdzie liczba periodyków lokalnych wzrosła z 35 w 1990 roku do 346 w 2002 roku $^{8}$. Jak się szacuje na początku 1989 roku ukazywało się w Polsce około 370-390 pism regionalnych, lokalnych i sublokalnych ${ }^{9}$. Ich liczba zaczynała w latach następnych systematycznie wzrastać. W 1999 roku ukazywało się w naszym kraju już 2428 tytułów lokalnych ${ }^{10}$. Najwięcej pism na 10 tysięcy mieszkańców przypada w województwach, według kolejności: małopolskim $(0,86)$, lubuskim $(0,80)$, wielkopolskim $(0,79)$, podkarpackim $(0,71)$, opolskim $(0,70)$. Najmniej gazet i czasopism lokalnych jest na tak zwanej ścianie wschodniej i w centrum Polski.

Oczywiście wskaźniki te należy korelować zarówno z czynnikami społeczno-demograficznymi, jak również ekonomiczno-urbanizacyjnymi, które określają i charakteryzują ogólne warunki funkcjonowania społeczeństwa w poszczególnych regionach kraju.

Do czynników społeczno-demograficznych należy zaliczyć między innymi:

1) regionalne i miejscowe tradycje prasowo-wydawnicze,

2) społeczną i polityczną aktywność poszczególnych wspólnot lokalnych, organizacji, miejscowych władz,

3) liczbę ludności zamieszkującej dany region i jej przekrój społeczny, w tym: miejsce zamieszkania, rodzaj zajęć, wiek, wykształcenie itp.,

4) stopę bezrobocia, która oddziałuje na wskaźnik popytu na prasę.

Natomiast do czynników ekonomiczno-urbanizacyjnych:

1) ogólny stan zamożności społeczeństwa mierzony wielkością dochodu przypadającego na mieszkańca,

7 Por. R. Kowalczyk, Prasa lokalna $w$ województwie poznańskim $w$ latach 1989-1998, Poznań 1999, s. 35-44.

8 Por. R. Kowalczyk, Media lokalne i społeczeństwo (wybrane problemy na przykładzie prasy lokalnej w Wielkopolsce), Poznań 2003, s. 15-24.

9 Por. W. Chorąki, Polskie media lokalne i sublokalne 1989-1999, op. cit., s. 60.

10 Stan z dnia 31 maja 1999 roku. Por. W. Chorązki, Polskie media lokalne i sublokalne 1989-1999, op. cit., s. 66-67. 
2) liczba miast i ich mieszkańców oraz poziom rozwoju infrastruktury komunalnej,

3) liczba, wielkość i rozmieszczenie zakładów pracy,

4) wskaźniki wyposażenia mieszkań w odbiorniki radiowe i telewizyjne, telefon, komputer oraz sprzedaży gazet i czasopism.

\subsection{Dynamika wzrostu}

Mimo, że ogólna liczba tytułów wzrasta systematycznie z roku na rok, to jednak dynamika tego wzrostu jest zmienna. Określają ją w zasadzie trzy charakterystyczne zjawiska, umożliwiające wyodrębnienie okresów zarówno wzmożonego przyrostu ogólnej liczby tytułów, jak i regresu lub stagnacji. Kształtowały one nie tylko wymiar liczbowy piśmiennictwa, ale miały również istotny wpływ na jego zawartość i nakład. Oddziaływanie to miało charakter zarówno polityczny (wybory samorządowe, parlamentarne, prezydenckie, referendum, powstanie nowych partii i ruchów politycznych, konflikty), jak i społeczny (zwiększająca się aktywność różnych grup, organizacji lokalnych, wspólnot religijnych) oraz ekonomiczny (stagnacja lub rozwój gospodarczy, konkurencja, koncentracja własności w mediach i wzrost zaangażowania kapitału zagranicznego w prasie lokalnej).

Lata 1990-1992 charakteryzowały się systematycznym i dynamicznym wzrostem liczby nowych tytułów. Rok 1993 to czas regresu, po którym nastąpił przyrost nowych pism, który trwał do 1996 roku. Rok później nastąpił niewielki spadek liczby nowych wydawnictw, rekompensowany znacznym ich wzrostem w latach 1998-1999. Lata 2000-2002 to wyraźne i systematyczne zmniejszanie się liczby nowych inicjatyw prasowych. Proces ten oznacza osiagnięcie przez lokalny rynek prasowo-wydawniczy względnej równowagi i stabilizacji. A jednocześnie jest początkiem nowego etapu konkurencji między wydawnictwami, które poszukują nowych metod i środków zdobywania i utrzymania czytelników (konkursy z nagrodami, takimi jak wycieczki zagraniczne, dodatki tematyczne, różnego rodzaju gadżety). Walka o odbiorcę przybiera na sile. Jest trudna, często bezkompromisowa i nie zawsze czysta z punktu widzenia etycznego.

W rezultacie więc, jedne periodyki powstawały, inne zaś kończyły swój żywot. Naturalnej w tej sytuacji fluktuacji sprzyjały procesy konkurencji i koncentracji własności prasy, wpływając dość znacznie na wahania liczby pism likwidowanych $\mathrm{w}$ danym okresie. W sytuacji dynamicznego 
wzrostu liczby nowych wydawnictw, zwiększa się również konkurencja między nimi, która wymusza likwidację niektórych pism. Koncentracja własności w mediach, polegająca między innymi na wykupywaniu konkurencyjnych czasopism, prowadziła do wzrostu wpływów określonych wydawców i możliwości zaoferowania odbiorcom często lepszego i tańszego środka informacji. Są to zatem stosunkowo naturalne tendencje, jakie występują na rynku prasy lokalnej.

\section{Częstotliwość}

Częstotliwość ukazywania się wydawnictw lokalnych umożliwia wyodrębnienie następujących kategorii: dzienniki, tygodniki, dwutygodniki, miesięczniki, dwumiesieczniki, kwartalniki, półroczniki, roczniki oraz pisma wydawane nieregularnie. Najbardziej aktualnymi informacjami dysponują dzienniki, których w praktyce prasy lokalnej jest niewiele (mniej niż 1\%). Ukazują się one najczęściej dwa razy w tygodniu (zazwyczaj we wtorek i piątek).

Na miejscowym rynku prasowo-wydawniczym dominują miesięczniki (51\%). W następnej kolejności znajdują się m.in.: tygodniki (22\%), kwartalniki (8\%), dwutygodniki (7\%), dwumiesięczniki i pisma wydawane nieregularnie (po 4\%).

Ponad połowa miejscowych czasopism ukazuje się więc co miesiąc. Periodyki te stanowią zatem ważną kronikę lokalnych wydarzeń. Natomiast ujemną ich cechą jest ograniczona aktualność. Okoliczności te determinują ich zawartość, na którą składają się głównie przeglądy lokalnych uroczystości oraz sprawozdania z działalności miejscowych władz i organizacji. Prasa ta nie zaspokaja w wystarczającym stopniu potrzeb informacyjnych mieszkańców i odgrywa mniejszą rolę w procesie kształtowania opinii publicznej. Zatem jej wpływ na postawy i zachowanie odbiorców jest często iluzoryczny.

Prawie jedną piątą czasopism stanowią tygodniki, czyli tytuły o większej aktualności i użyteczności społecznej. Dostarczają one czytelnikom nie tylko stosunkowo świeżych wiadomości dotyczących życia miejscowego środowiska, ale są także efektywnym środkiem reklamy dla lokalnych przedsiebiorców. Ich aktualność, stosunkowo duży nakład, profesjonalizm edytorsko-dziennikarski powodują, że stają się one ważnym czynnikiem wpływu na miejscową opinię publiczną. Nieco gorszymi parametrami tak rozumianej efektywności dysponują dwutygodniki. Kronikarski, eduka- 
cyjny i propagandowy charakter mają dwumiesieczniki, kwartalniki i czasopisma ukazujące się nieregularnie.

\section{Naklad}

Nakład czasopisma nie zawsze odpowiada potrzebom miejscowego czytelnika. Często jest zdeterminowany możliwościami wydawcy oraz liczbą mieszkańców danej jednostki terytorialnej, jak również konkurencją istniejącą na lokalnym rynku prasowo-wydawniczym. Ponadto jest to czynnik, który należy odróżnić od wskaźnika sprzedaży, wyznaczającego rzeczywisty popyt na dany periodyk. Zazwyczaj sprzedaż prasy lokalnej jest mniejsza od nakładu, niekiedy nie przekracza nawet 50\%. Czesto wydawnictwa zawyżają nakłady, które są istotnym wskaźnikiem dla reklamodawców, wyznaczającym minimalną cenę dotarcia $\mathrm{z}$ inseratem do potencjalnego odbiorcy, a ukrywają dane dotyczące faktycznej sprzedaży. Dlatego należy stosunkowo ostrożnie podchodzić do podawanych przez nich wielkości.

Pismiennictwo lokalne nie należy do wielkonakładowych. Aż 90\% miejscowych tytułów mieści się w nakładzie do 6000 egz. Zaledwie 10\% przekracza ten nakład. Zaś prawie 50\% ukazuje się w nakładzie do 1000 egz. Około $25 \%$ nie przekracza 500 egzemplarzy. Większy nakład mają najczęściej pisma ukazujące się z większą częstotliwością - tygodniki i dwutygodniki. Są wśród nich wydawnictwa prywatne o charakterze komercyjnym i czasopisma większych jednostek samorządowych (miast, gmin, powiatów), często bezpłatnie kolportowane wśród mieszkańców.

\section{Zasięg rozpowszechniania}

Wskaźnik ten wyznacza granice obszaru rozpowszechniania określonego pisma. Prasa lokalna jest kolportowana w gminach, miastach, miastach-gminach, powiatach, parafiach, osiedlach i w niektórych wsiach. Mając na uwadze ten czynnik, możemy mówić o prasie gminnej, miejskiej, miejsko-gminnej, powiatowej, parafialnej, osiedlowej i wiejskiej.

Najwięcej czasopism jest kolportowanych w powiatach (29\%) i miastach-gminach (28\%), co oznacza, że na obszarze tych jednostek rozpowszechnia się prawie $3 / 5$ prasy lokalnej. Wśród pism ukazujących się w powiatach najwięcej, bo $17 \%$ tytułów, kolportuje się w jednym powiecie, w dwu powiatach $7 \%$, a na obszarze od 3 do 6 powiatów $-5 \%$. W na- 
stępnej kolejności znajdują się periodyki rozpowszechniane w: gminach $(15 \%)$, parafiach $(13 \%)$, osiedlach $(8 \%)$ i miastach $(6 \%)$.

\section{Wydawcy}

Wsród wydawców prasy lokalnej wyodrębnia się m.in. podmioty prywatne (jednoosobowe firmy, s.c. i sp. z o.o.), samorządy terytorialne gmin i powiatów oraz ich jednostki organizacyjne (urzędy gmin i miast, zarządy powiatów i starostwa, rady gmin i miast oraz powiatów, biblioteki, domy kultury, muzea, gospodarstwa pomocnicze samorządów terytorialnych), parafie, partie i organizacje polityczne, samorządy pomocnicze (rady osiedlowe i sołeckie), stowarzyszenia i fundacje, spółdzielnie.

Najwięcej jest wydawców prywatnych (37\%): zorganizowanych w formie jednoosobowych firm prasowo-wydawniczych (25\%), spółek z ograniczoną odpowiedzialnością (10\%) i spółek cywilnych (2\%).

$\mathrm{Na}$ drugim miejscu znajdują się pisma samorządów gmin (31\%): wydawane przez urząd gminy (25\%), dom kultury (4\%), bibliotekę i gospodarstwo pomocnicze (1\%).

Na trzecim miejscu są tytuły parafialne (13\%). W następnej kolejności znajdują się wydawnictwa m.in.: stowarzyszeń (8\%), samorządów pomocniczych gmin - osiedlowych i sołeckich (5\%), samorządów powiatu $(2 \%)$, partii politycznych $(1 \%)$.

\section{Transformacja prasy lokalnej}

Do charakterystycznych zjawisk, jakie towarzyszyły transformacji prasy w Polsce badacze zaliczają w szczególności: 1) destabilizację i dekompozycję, 2) demonopolizację i decentralizację, 3) polaryzację i pluralizację, 4) rywalizację i brutalizację, 5) komputeryzację i technicyzację ${ }^{11}$.

W odróżnieniu od transformacji prasy w ogóle, rozwój wydawnictw lokalnych charakteryzował się niektórymi cechami właściwymi tylko temu segmentowi mediów. Co doprowadziło do wyraźnego wyodrębnienia się tej kategorii prasy i uczyniło ją przedmiotem odrębnych badań i analiz. Transformacja prasy lokalnej miała więc stosunkowo oryginalny

11 Por. A. Słomkowska, Stowo wstęne, w: Transformacja prasy polskiej (1989-1992), pod red. A. Słomkowskiej, Warszawa 1992, s. 7. 
charakter oraz częściowo odmienną, wyróżniającą ją od pozostałych wydawnictw, specyfikę. Dlatego, badając proces przeobrażeń prasy lokalnej w latach 90., możemy mówić o takich zjawiskach, jak: 1) restytucja, 2) koncentracja i monopolizacja, 3) unifikacja i standaryzacja, 4) polaryzacja i pluralizacja, 5) rywalizacja, 6) brutalizacja i wulgaryzacja, 7) komputeryzacja i technicyzacja.

\subsection{Restytucja}

W konsekwencji możemy mówić nie o destabilizacji i dekompozycji, lecz raczej o restytucji tej charakterystycznej grupy typologicznej prasy, która po 1989 roku przeżywa swoisty renesans. Następował systematyczny przyrost liczbowy tytułów. Stosunkowo szybko kształtowała się struktura rodzajowo-typologiczna prasy lokalnej, której zainteresowania i funkcje wyznaczały potrzeby miejscowego odbiorcy i interesy określonych środowisk. Rynek prasy lokalnej powiększał się zarówno ilościowo, jak i terytorialnie, ulegając także określonym przekształceniom jakościowym. Wymienione zjawiska prowadziły w rezultacie do koncentracji własności prasy i do jej monopolizacji.

\subsection{Koncentracja i monopolizacja}

Wielu dotychczas niezależnych wydawców, ulegając presji rynku i konkurencji, decydowało się na sprzedaż pisma (często kupcowi zagranicznemu) lub też połączenie $\mathrm{z}$ innym edytorem w większą grupę medialną. W konsekwencji koncentracji własności w rękach coraz mniejszej liczby właścicieli, tworzyły się dogodne warunki powstania monopolu na obszarze wyznaczonym zasięgiem kolportażu konkretnego wydawnictwa. Sytuacja ta prowadziła zazwyczaj do homogamii prasy. Nie zawsze jednak wiązało się to ze zmniejszeniem oferty programowej, a wręcz odwrotnie: często prowadziło do jej powiększenia. Co odpowiadało potrzebom miejscowego czytelnika.

\subsection{Unifikacja i standaryzacja}

W prasie o charakterze lokalnym obserwujemy proces unifikacji, który wyraża się ujednoliceniem zakresu zainteresowań, zasięgu rozpowszechniania, formy i stylu wypowiedzi oraz podziału zawartości na wyraźnie wyodrębnione działy. Coraz częściej poszczególne wydawnictwa lokalne 
różnią się głównie winietą, podczas gdy ich zawartość ulega wyraźnej standaryzacji. Zjawisko to oznacza dostosowywanie oferty nadawców do potrzeb przeciętnych odbiorców, którzy zanurzeni w homogenicznej i masowej kulturze poszukują standaryzowanych i stosunkowo tanich produktów zawierających różnorodne treści.

\subsection{Polaryzacja i pluralizacja}

Lokalny rynek prasowy ulegał także pewnemu rodzajowi polaryzacji, której efektem jest funkcjonowanie obok siebie pism różniących się tematycznie, programowo, ideowo i politycznie. Stąd też w ich zawartości obserwuje się wyraźne różnice, które są związane najczęściej z charakterystycznymi sposobami definiowania i opisu rzeczywistości - z właściwej danej grupie społecznej perspektywy ideowej, politycznej, programowej, obyczajowej, światopoglądowej, religijnej. Sytuacja ta prowadzi często do konfrontacji między tymi wydawnictwami, która wyraża się nie tylko w zachowaniach werbalnych, lecz także w dziedzinie faktycznej walki o czytelnika i reklamodawcę. Zjawisko polaryzacji można również rozumieć jako skłonność dziennikarzy do przedstawiania rzeczywistości w kategoriach przeciwieństw.

Następnym charakterystycznym przejawem transformacji prasy lokalnej jest jej pluralizacja, która prowadzi z jednej strony do powstania charakterystycznych grup rodzajowych o wyodrębnionych zainteresowaniach. Sa to jednak często grupy dychotomiczne, niekiedy nawet przeciwstawne sobie. Dzieje się tak wtedy, gdy mimo wspólnego zakresu zainteresowań (na przykład pisma ogólnoinformacyjne), dzieli je specyficzny, często oryginalny sposób selekcji materiałów przeznaczonych do rozpowszechniania oraz analizy i oceny rzeczywistości (na przykład prasa partyjna, samorządowa, parafialna) ${ }^{12}$. $Z$ drugiej zaś strony zjawisko pluralizacji odnosi się do wielości prezentowanych w mediach treści, poglądów, idei, wartości, ocen, zasad postępowania.

\subsection{Rywalizacja}

W warunkach gry rynkowej celem wydawnictw prasowych jest rywalizacja z innymi nadawcami o odbiorców. W ten sposób prasa, poszerzając

12 Zob. Kraina lokalności. Rzecz o polskiej prasie lokalnej, pod red. M. Kujawskiego, współpraca A. Hejman, Fundacja IDEE, Warszawa 2001. 
zasięg czytelnictwa, wzmacnia jednocześnie swoją pozycję na rynku. Efektem takich zachowań jest wzrost nakładu pisma. W rezultacie zazwyczaj zwiększają się dochody przedsiębiorstwa. Zmienia się jego sytuacja ekonomiczna i wzrasta zainteresowanie tytułem ze strony reklamodawców i ogłoszeniodawców. Korzyści ekonomiczne poprawiające ogólną sytuację wydawnictwa na rynku mediów, usprawiedliwiają zachowanie dziennikarzy (wydawców), którzy w pogoni za sensacją epatują odbiorców zbrodnią, tragicznym wydarzeniem oraz penetrują prywatną sferę życia obywateli. Tym sposobem do prasy lokalnej przenika coraz więcej wyrażeń potocznych ${ }^{13}$. W konsekwencji tytuły miejscowe, odzwierciedlając otaczającą rzeczywistość, są ilustracją lokalnej kultury ${ }^{14}$, której fundamentem jest między innymi określony sposób porozumiewania się ludzi i związane z nim słownictwo. W ostateczności prasa lokalna również oddziałuje na otoczenie i kształtuje miejscową kulturę ${ }^{15}$.

\subsection{Brutalizacja i wulgaryzacja}

Negatywnym skutkiem rywalizacji wydawców prasy o jak największą liczbę czytelników są takie działania dziennikarzy, w których wykorzystuje się wszelkie możliwe sposoby i formy zaciekawienia odbiorcy. Nadawcy dążą więc do maksymalnego uatrakcyjnienia przekazu, które uzyskuje się między innymi poprzez zamieszczanie obrazów brutalnych scen i przemocy oraz brutalizację i wulgaryzację języka. Mają one nie tylko zaciekawić odbiorcę, ale także szokować.

Z punktu widzenia obyczaju językowego szczególnie niepokojącym jest zjawisko wulgaryzacji w opisie rzeczywistości. Prowadzi ono do spłycania i upraszczania myśli, poglądów, idei, aby w konsekwencji zniekształcić wartościowe sądy i opinie oraz wypaczyć właściwe proporcje między zjawiskami. Zachowanie takie często jest naturalnym przejawem frustracji społecznej lub przekory wobec rytualizacji życia, a także stano-

13 Por. K. Mosiołek-Kłosińska, Ślady polskich przemian po 1989 roku w słownictwie ogólnym, w: Polszczyzna w komunikowaniu publicznym, pod red. W. Gruszczyńskiego, J. Bralczyka, G. Majkowskiej, Warszawa 1999, s. 42.

${ }_{15}$ Zob. J. Kmita, O kulturze symbolicznej, Warszawa 1982, passim.

15 Zob. Biologiczne $i$ społeczne uwarunkowania kultury, pod red. J. Kmity i K. Łastowskiego, Warszawa-Poznań 1992, passim. 
wi wyraz nieposłuszeństwa wobec określonej tradycji, która już nie odpowiada potrzebom szybko zmieniającej się rzeczywistości ${ }^{16}$.

\subsection{Komputeryzacja i technicyzacja}

Nowe techniki zbierania i przesyłania informacji oraz komputerowego opracowania tekstu, a także zastosowanie nowoczesnych technologii dru$\mathrm{ku}$ - to technicystyczne wymiary współczesnego obrazu prasy lokalnej. Obecnie większość wydawców wykorzystuje w codziennej pracy najnowsze osiagnięcia techniczne i technologiczne. Mają one zastosowanie zarówno podczas komputerowego składu, łamania i opracowania graficznego pisma, jak i w czasie druku oraz zbierania i przesyłania informacji (internet, poczta elektroniczna, telefon komórkowy, dyktafon, notebook, cyfrowy aparat fotograficzny). W rezultacie nowe osiagnięcia techniczne nie tylko usprawniają produkcję prasy, począwszy od zbierania materiałów, poprzez ich opracowanie i korektę, przesyłanie informacji na odległość oraz druk i dystrybucję, ale wpływają również na podniesienie jakości przekazów prasowych i zwiększenie estetycznych walorów pisma.

\section{Summary}

This paper analyzes the transformation of the Polish local press in the 1990's. The author begins by outlining the situation of both the legal and the underground press in the 1980's. He describes the political, social, economic and legal determiners of the transformation and the main factors affecting the changes of that time. Next he analyzes the quantitative growth in the number of titles, their frequency, circulation and range as well as the profiles of their publishers. Finally, he discusses the most significant aspects of transformation of the local press, including the issue of concentration and monopolization of the local press, competition between the publishers and the influence of technology and IT in particular on these media. The author also observes the adverse changes of the media related to the increasingly common brutality and vulgarity of the language.

16 Por. J. Puzynina, Stowo - wartość - kultura, Lublin 1997, s. 126. 